\title{
Diurnal variation of lymphocyte subsets identified by monoclonal antibodies
}

\author{
JAMES V BERTOUCH, PETER J ROBERTS-THOMSON, JOHN BRADLEY
}

\begin{abstract}
Monoclonal antibodies specific for lymphocyte subsets were used to examine circulating lymphocytes obtained at frequent intervals from healthy subjects. A diurnal rhythm was found in the total numbers of lymphocytes, $T$ cells, inducer/helper cells, suppressor/cytotoxic cells, Ia positive cells, and $B$ cells. The lowest levels of all subsets were seen at 0900 hours and the highest levels at 2100. In some subjects the ratio of helper to suppressor cells varied considerably during the sample period, though the ratio was relatively constant for the group as a whole.
\end{abstract}

\section{Introduction}

Diurnal variation in the numbers of circulating leucocytes in man is well recognised. Exposure to light and subsequent effect on the hypothalamic-pituitary adrenal axis is considered to be the probable mechanism, though exercise, food, and emotion may also be implicated. Studies of diurnal variations of $T$ and $B$ lymphocytes have mainly utilised rosetting techniques, mitogenic responses, and identification of surface immunoglobulins and $F_{c}$ receptors. ${ }^{1-4}$ The discovery of monoclonal antibodies specific for lymphocyte subsets prompted an examination for the presence of diurnal rhythms in these subsets. We have used a panel of monoclonal antibodies to identify lymphocyte populations in blood taken at three hourly intervals from a group of healthy laboratory workers.

\section{Subjects and methods}

We studied nine healthy male volunteers from laboratory staff. Their mean age was 35 years (range 29-49), and none was taking any form of medication. Blood was collected from 0600 to 2100 hours at three hourly intervals. White cell counts were performed with a Coulter counter and differential counts measured in blood smears stained with Giemsa. All differential counts were performed by the same observer. Serum cortisol concentrations were measured by radioimmunoassay in a single batch for each subject (normal range $140-690 \mathrm{nmol} / 1 ; 5 \cdot 0-25 \cdot 0 \mu \mathrm{g} / 100 \mathrm{ml}$ ).

Mononuclear cells were separated from each sample of heparinised blood on a Ficoll-Hypaque gradient. All separations and subsequent preparative steps were performed by the same person. The cells were washed three times in Dulbecco's phosphate buffered saline and the final concentration adjusted to $10 \times 10^{6}$ cells $/ 1$. A $50 \mu 1$ sample of this suspension was incubated for 20 minutes with an appropriate volume of each of a panel of monoclonal antibodies. These included FMC 16 positive control ( $\beta_{2}$-microglobulin; I Beckman, unpublished observations) $\times 63$ negative control (supernatant from $1 \mathrm{gG} 1$ mouse myeloma cell line), FMC 1 (B cells), ${ }^{5}$ FMC 4 (Ia positive cells), ${ }^{6} \mathrm{~T} 28$ (T cells),

Department of Clinical Immunology, Flinders Medical Centre, Adelaide 5042, South Australia

JAMES V BERTOUCH, FRACP, research fellow

PETER J ROBERTS-THOMSON, FRACP, staff specialist

JOHN BRADLEY, FRCP, professor of clinical immunology

Correspondence to: Professor John Bradley, Department of Clinical Immunology, Flinders Medical Centre, Bedford Park, South Australia 5042.
OKT 4 (inducer/helper), and OKT 8 (suppressor/cytotoxic; Ortho Pharmaceutical Corporation, NJ, USA). After washing, a second 20 minute incubation with fluorescein isothiocyanate labelled goat antimouse antibody was performed. After two washes with Dulbecco's phosphate buffered saline the cells were resuspended in this solution and the percentage of positively fluorescent lymphocytes measured on a Becton Dickinson FACS IV flow cytometer. The same observer measured all percentages using both forward and 90 degree light scatter to delineate lymphocytes from other cells.

After analysis of the initial samples from each subject the flow cytometer was programmed to use the same cursor positions (measurement parameters) for all further samples from that subject. This was done to eliminate any observer bias.

The absolute numbers of each subset were calculated by multiplying the percentage of positively fluorescent cells by the total number of lymphocytes obtained from the blood smear. The results were analysed using Friedman's two way analysis of variance by ranks. Mean and standard errors for each sample time were calculated from logarithmic data and the results plotted on semilogarithmic graph paper.

\section{Results}

There was a diurnal rhythm in the total lymphocyte count and all subsets, with a minimum count at 0900 hours and a maximum count at 1800-2100 (figure). Analysis of these results showed a highly significant degree of variance $(p<0.005)$. The helper :suppressor cell ratio for the whole group was remarkably constant at roughly $2: 1$ throughout the test period. Nevertheless, large individual variations occurred-for example, in subjects 1 and 3 (table). Serum cortisol concentrations peaked at 0600 hours and then fell throughout the day to 2100 hours (figure).

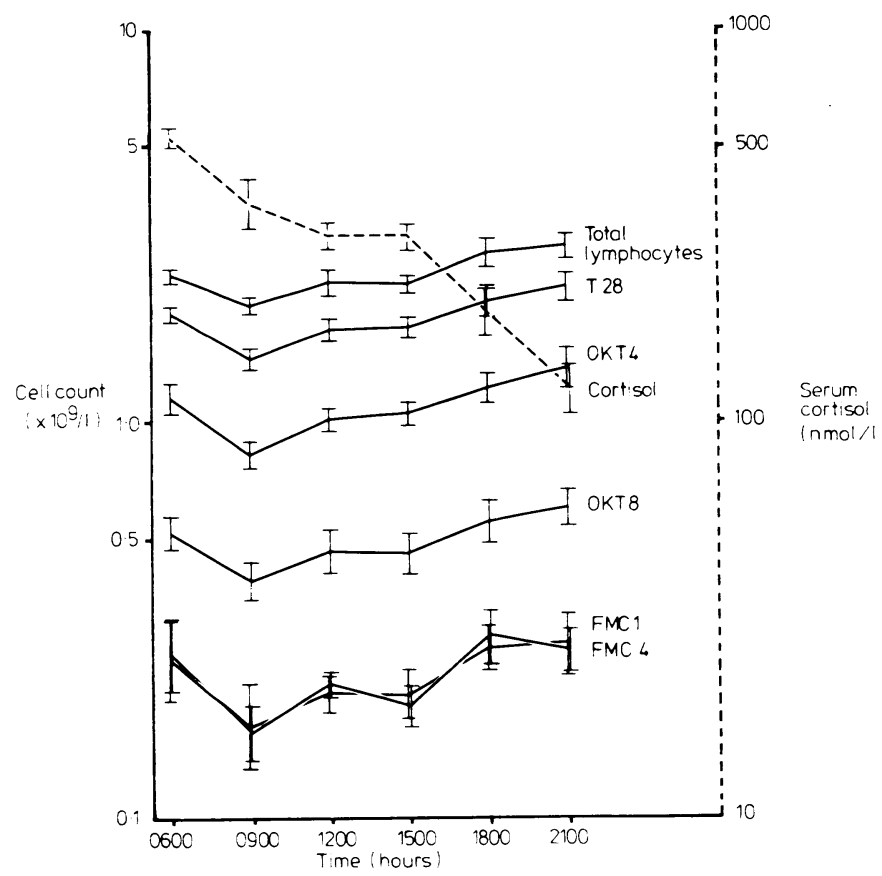

Mean ( $\pm S E M)$ numbers of peripheral lymphocytes and corresponding subsets at each sample time (solid lines) and mean ( \pm SEM) serum cortisol concentration for each sample time (dashed line). Samples taken from 0600 to 2100 hours.

Conversion: SI to traditional units-Cortisol: $1 \mathrm{nmol} / 1 \approx 0.04 \mu \mathrm{g} / 100 \mathrm{ml}$. 
Helper:suppressor cell ratios in all subjects during test period

\begin{tabular}{|c|c|c|c|c|c|c|c|c|c|}
\hline \multirow{2}{*}{$\begin{array}{c}\text { Time } \\
\text { (hours) }\end{array}$} & \multicolumn{9}{|c|}{ Subject No } \\
\hline & 1 & 2 & 3 & 4 & 5 & 6 & 7 & 8 & 9 \\
\hline $\begin{array}{l}0600 \\
0900 \\
1200 \\
1500 \\
1800\end{array}$ & $\begin{array}{l}1 \cdot 1 \\
2 \cdot 7 \\
2 \cdot 1 \\
2 \cdot 3 \\
2 \cdot 2\end{array}$ & $\begin{array}{l}2 \cdot 8 \\
1 \cdot 7 \\
2 \cdot 0 \\
2 \cdot 0 \\
2 \cdot 2\end{array}$ & $\begin{array}{l}4 \cdot 9 \\
3 \cdot 2 \\
5 \cdot 5 \\
5 \cdot 4 \\
4 \cdot 9\end{array}$ & $\begin{array}{l}2 \cdot 3 \\
1 \cdot 9 \\
2 \cdot 1 \\
2 \cdot 2 \\
2 \cdot 4\end{array}$ & $\begin{array}{l}1.7 \\
1.9 \\
1.5 \\
1.8 \\
1.6\end{array}$ & $\begin{array}{l}3 \cdot 6 \\
2.5 \\
2 \cdot 6 \\
3 \cdot 2 \\
2 \cdot 8\end{array}$ & $\begin{array}{l}1.8 \\
1.6 \\
1.9 \\
1.6\end{array}$ & $\begin{array}{l}1.5 \\
1.2 \\
1.4 \\
1.2 \\
1.4\end{array}$ & $\begin{array}{l}2 \cdot 1 \\
2 \cdot 0 \\
2 \cdot 6 \\
2 \cdot 3 \\
2 \cdot 1\end{array}$ \\
\hline
\end{tabular}

\section{Discussion}

Our findings confirm the known diurnal rhythm of total lymphocyte numbers and illustrate the similar rhythm of several lymphocyte subsets as identified by monoclonal antibodies. We examined only men, as the effect on subsets of the menstrual cycle and other factors such as oral contraceptives is not known. When absolute cell numbers were examined the largest diurnal variations occurred in total $\mathrm{T}$ cell and helper cell populations. Suppressor cells showed less variation, and the least change was seen in B cells and Ia positive cells. These last two populations have a close correlation, which is further evidence for the concept of circulating Ia positive cells usually belonging to the $\mathrm{B}$ cell class. The ratio of helper to suppressor cells was remarkably constant for the whole group (figure). The mean figures, however, had large standard errors, and hence variations occurred in every subject. The table shows the ratios for all subjects, and in two (subjects 1 and 3) the ratio doubled during the test period. These two subjects were re-examined and similar pronounced changes in ratios again seen. Possibly some normal subjects may always show this degree of change in ratios, and further studies are required to examine this. Hence ratios calculated from samples obtained at different times of the day must be compared with caution.

The diurnal rhythm is presumably secondary to compartmentalisation of lymphocytes in various organs such as lymph nodes, spleen, and bone marrow. Endogenous glucocorticoids are probably at least partially responsible for this. ${ }^{24}$ Kinetic studies of radiolabelled lymphocytes show redistribution of the recirculating population out of the vascular compartment into peripheral lymphoid organs after administration of glucocorticoids. :-9 In our study the relation between serum cortisol concentrations and cell counts was not directly inverse, as the mean peak of cortisol values was at 0600 , while cell counts were lowest three hours later. A postulated delay in the cortisol redistribution through body compartments before exerting an effect may account for this. Evidence for this proposal may be found from other studies where the maximum depressive effect of oral prednisolone was not seen for several hours after the dose. ${ }^{710}$

In conclusion we found a highly significant diurnal rhythm for several lymphocyte subsets. There was no disproportionate change in any particular subpopulation. The rhythm may be due to the effect of endogenous cortisol. Variations in the total lymphocyte count reflect similar changes in different subpopulations.

JVB is a grateful recipient of a National Health and Medical Research Council postgraduate scholarship. We thank J Webster for flow cytometry measurements and R McEvoy for differential white cell counts. Cortisol measurements were performed by the department of clinical biochemistry, and the department of haematology prepared the blood films. T 28 was a gift from PCL Beverley, ICRF, Human Tumour Immunology Group, University College London. The typescript was prepared by Marlene Molnar.

\section{References}

1 Bartter FC, Delea CS. A map of blood and urinary changes related to circadian variations in adrenal cortical function in normal subjects. $A n n$ NY Acad Sci 1962;98:969-75.

2 Tavadia HB, Fleming KA, Hume PD, Simpson HW. Circadian rhythmicity of human plasma cortisol and PHA induced lymphocyte transformation. Clin Exp Immunol 1975;22:190-3.

${ }^{3}$ Abo T, Kumagai K. Studies of surface immunoglobulins on human B lymphocytes. III. Physiological variations of SIg cells in peripheral blood. Clin Exp Immunol 1978;33:441-52.

+ Abo T, Kawate T, Itoh K, Kumagai K. Studies on the bioperiodicity of the immune response. I. Circadian rhythms of human $T, B$ and $K$ cell traffic in the peripheral blood. F Immunol 1981;126:1360-3.

'Brooks DA, Beckman I, Bradley J, et al. Human lymphocyte markers defined by antibodies derived from somatic cell hybrids. II. A hybridoma secreting antibody against a marker specific for human B lymphocytes. Clin Exp Immunol 1980;39:477-85.

' Beckman IGR, Bradley J, Brooks DA, et al. Human lymphocyte markers defined by antibodies derived from somatic cell hybrids. I. A hybridoma secreting antibody against an antigen expressed by human $\mathrm{B}$ and null lymphocytes. Clin Exp Immunol 1980;40:593-601.

' Fauci AS, Dale DC. Alternate day prednisolone therapy and human lymphocyte subpopulations. $\mathcal{F}$ Clin Invest 1975;55:22-32.

${ }^{8}$ Fauci AS. Mechanism of corticosteroid action on lymphocyte subpopulations. I. Redistribution of circulating $\mathrm{T}$ and $\mathrm{B}$ lymphocytes to the bone marrow. Immunology 1975;28:669-80.

${ }^{9}$ Fauci AS. Glucocorticoid effects on circulating human mononuclear cells. f Reticuloendothel Soc 1979; suppl:727-38.

10 Yu DT, Clements PJ, Paulus HE, et al. Human lymphocyte subpopulations. Effect of corticosteroids. F Clin Invest 1975;53:565-71.

(Accepted 19 February 1983)

$=$

ONE HUNDRED YEARS AGO Sir James Hanbury, late Principal Medical Officer of the Army under Lord Wolseley in Egypt, was under examination before Lord Morley's Committee on Friday, the 19th instant, and again in the course of the present week. Several matters will probably be cleared up when the evidence given by this medical officer, who, of course, holding the high position which he did, was Lord Wolseley's chief medical adviser in sanitary matters, is published. Among other points, we may hope to get an explanation regarding the issue of spirit-rations to the troops in Egypt. The distribution of spirits to the troops was quite contrary to the views of the commander-in-chief, if we may take as accurate the report of Lord Wolseley's recent speech to the temperance societies at Blackburn, which appeared in the Times of the 19th instant. According to the report referred to, Lord Wolseley told the deputations that he himself firmly believed that, if we could only have an army which not only wore Her Majesty's colours, but also the blue ribbon, it would be the finest army ever sent into the field to represent this country; yet, during the recent campaign in Egypt, "the doctors told him it was very necessary that the men should have grog; and he was obliged, owing to great pressure put upon him, to allow it occasionally." The recorded experience of some of the ablest medical officers has shown that alcoholic drinks neither give help as regards bodily exertion, nor protect the constitution against the invasion of disease, and, with respect to hot climates, that they aggravate rather than lessen the effects of heat; moreover, Lord Wolseley was able to quote, with regard to Egypt itself, that, during Sir Ralph Abercrombie's expedition to that country in the year 1800, the good conduct and health of the troops landed were attributed to the fact that no liquor was issued to them-testimony which was confirmed by Sir James McGrigor in his Medical Sketches of the Expedition to Egypt. Under all these circumstances, it seems strange that the issue of grog to the men should have been pressed upon the commander-in-chief of the army recently engaged in active operations in Egypt by the medical officers. As, however, the particular conditions under which the advice was given have not as yet been published, it seems only right to abstain for the present from comments on the observations made by Lord Wolseley on the subject to the deputations from the Blackburn temperance societies. It is greatly to be hoped that the opportunity of forming an impartial judgment on the subject will be afforded when the report of Lord Morley's Committee, and the evidence on which the report will be based, have been presented to Parliament. The matter is one of more than passing interest. (British Medical fournal $1883 ; \mathrm{i}: 169$.) 